\title{
MANIFESTASI SEKSUALITAS \\ DALAM BUDAYA KEBEBASAN
}

Rusydi Hikmawan*

\section{Abstract}

This time, pornography and erotic actions start to correlate into culture domain, where human beings become the subject as well as the object. Concept of culture claims the relationship between buman interaction on society and culture as a result of them. Pornography and erotic actions are considered to be the representation of the products of human being activities in the forms of technology, pictures, idols, painting etc. All of them are then absorbed into culture.

The opponents of freedom culture suggest that Indonesian people should be responsible to the development of Indonesian culture which is based on religions and eastern norms. The most dominant norms is Islamic teaching which is the religion of the majority of the citizen. Thus, Indonesia culture should be able to represent Islamic way of life which is based on al Quran and Sunnah. Pornography, which is against Islamic teaching should not be part of Indonesian culture.

Keywords: Pornografi, Pornoaksi, Akulturasi Budaya, Etika, Kebebasan.

DEWASA ini, kebudayaan Indonesia dihadapkan dengan kebudayaan impor, berupa kebebasan berekspresi. Budaya tersebut masih sulit diterima oleh masyarakat Indonesia, karena masyarakat Indonesia masih terikat secara kultural di wilayahnya

*Penulis adalah aktifis kelompok Studi Kependidikan dan Keislaman NTB, yang beralamat di Jln. Kahayan No. 4 BTN Kekalik, Mataram NTB. email: rusydi_pii_ntb@yahoo.com 
dan terikat oleh agama secara normatif. Ini merupakan tantangan berat bagi masyarakat Indonesia. Budaya kebebasan berekspresi ini berupa pornografi dan pornoaksi berasal dari negara Barat yang notabene menggunakan ideologi sekuler. Pornografi dan pornoaksi merupakan kegiatan mempertontonkan atau memamerkan bagian tubuh pribadi ke orang lain atau khalayak ramai. Perbedaan antara pornografi dan pornoaksi terletak pada efek yang ditimbulkannya, pornografi lebih bersifat pasif, dalam bentuk gambar dua dimensi dan rangsangan yang timbul karena kinerja hormonal dalam tubuh yang melihatnya, sedangkan pornoaksi menekankan adanya usaha aktif untuk memberikan rangsangan seksual bagi yang melihatnya. ${ }^{1}$

Pornografi dan pornoaksi dalam tataran hasil kebudayaan adalah ketika pornografi dan pornoaksi sebagai proses pencurahan diri (akal) manusia secara terus menerus di dunia melalui aktivitas fisik dan nonfisik. Argumen tersebut tidak salah dalam ranah kebudayaan yang selalu bersifat relatif. Hal tersebut tergantung pada batasan penilaian yang didasari oleh waktu, tempat, dan siapa yang menilai, ${ }^{2}$ sehingga sulit untuk menjustifikasi kebenaran dan letak kesalahan suatu budaya yang belum diterima oleh budaya dalam konteks keindonesiaan. Budaya dalam konteks tersebut merupakan budaya masyarakat Indonesia yang masih kaku, tradisional, dan primitif yang sangat ditentukan oleh nilai-nilai religius. Relativisme etika yang terbentuk dalam diskursus pornografi dan pornoaksi dalam tataran budaya karena tidak adanya prinsip moral yang berlaku secara universal.

${ }^{1}$ Sebenarnya perbuatan yang termasuk pornografi dan pornoaksi bukan semata-mata hanya perbuatan erotis yang membangkitkan nafsu birahi, tetapi juga termasuk perbuatan erotis dan atau sensual yang memuakkan, menjijikkan, atau memalukan orang yang melihatnya atau mendengarnya, atau menyentuhnya. Lihat Neng Djubaedah, Pornografi dan Pornoaksi Ditinjau Dari Hukum Islam (Jakarta: Kencana, 2003), 85.

I'Ibid., 34. 
Ketika pornografi dan pornoaksi sebagai hasil budaya, maka budaya tersebut erat kaitannya bagaimana budaya tersebut tercipta. Budaya juga tidak dapat dipisahkan dari tatanan nilai etika di mana budaya tersebut digunakan oleh masyarakat. Budaya merupakan sebuah sistem yang mempunyai koherensi bentuk-bentuk simbolis yang berupa kata, benda, laku, mite, sastra, lukisan, nyanyian, musik, dan kepercayaan yang mempunyai kaitan erat dengan konsep-konsep epistemologis dari sistem pengetahuan masyarakatnya. Unsur kebudayaan berupa simbol tersebut dapat digunakan untuk mengekspresikan atau memberi makna. ${ }^{3}$ Banyak simbol berupa objek-objek fisik yang telah memperoleh makna kultural dan dipergunakan untuk tujuan-tujuan yang lebih bersifat simbolik. Gambar payudara wanita, misalnya, sesungguhnya tidak lain merupakan bagian dari simbol feminisme tubuh yang dihormati dengan menutupinya. Tetapi saat ini simbol berupa gambar tersebut hanya dimaknai sebagai erotisme yang memiliki tingkat kepuasan dan kenikmatan oleh masyarakat Indonesia sebagai bagian dari pengaruh tataperilaku budaya Barat. Atas dasar itu kajian ini akan mendeskripsikan serta mempertegas nilai yang terkandung dalam simbol-simbol erotisme dalam kebudayaan Barat yang mendistorsi tataperilaku budaya di Indonesia.

\section{Akulturasi Budaya Berekspresi Indonesia dan Barat}

Budaya menempati posisi sentral dalam seluruh tatanan hidup manusia, tidak ada manusia yang dapat hidup di luar lingkup budaya. Selain itu, budaya telah memberi nilai dan makna pada kehidupan manusia, kebudayaan adalah suatu fenomena universal. Budaya satu dengan lainnya di seantero jagad bumi tidaklah sama segi bentuk maupun coraknya. Manusia sebagai cultural being merupakan manusia sebagai

${ }^{3}$ Rafael Raga Maran, Manusia dan Kebudayaan: Dalam Perspektif Ilmu Budaya Dasar (Jakarta: Rineka Cipta, 2000), 43. 
makhluk berbudaya melalui fakta historis. Sebagai cultural being, manusia adalah pencipta kebudayaan, dan sebagai ciptaan manusia budaya adalah ekspresi eksistensi manusia di masingmasing masyarakat. ${ }^{4}$ Interaksi kreatif antara masyarakat dengan kondisi geografi setempat, akhirnya membentuk budaya. Ada tiga tahap yang menjadikan budaya sebagai produk masyarakat Indonesia, yakni: eksternalisasi, objektifikasi, dan internalisasi. ${ }^{5}$

Tataperilaku budaya Barat berupa kebebasan berekspresi oleh masyarakat Indonesia masih dalam proses akulturasi dan adaptasi budaya di luar tatanan budaya masyarakat setempat. Sehingga, budaya Barat tersebut mulai terkondisikan dengan tatanan budaya di Indonesia. Saat ini budaya di Indonesia lebih bersifat sektoral dan tradisional sedang dihadapkan pada budaya Barat yang bersifat "universal dan modern". Pesan-pesan simbolis tersebut melekat pada benda-benda hasil budaya moderen yang hanya dapat dipahami oleh mereka yang telah terdidik atau terbiasa menerima pesan-pesan simbolis tersebut. ${ }^{6}$ Budaya dalam bentuk simbol sebagai hasil pemikiran manusia, dengan kemampuan berkomunikasi melalui simbol inilah yang

\section{${ }^{4}$ Ibid., 15.}

${ }^{5}$ Eksternalisasi adalah proses pencurahan dari masyarakat secara terus menerus ke dalam dunia melalui aktivitas fisik dan nonfisik. Objektifikasi adalah tahap di mana aktivitas manusia menghasilkan suatu realitas objektif yang berada di luar masyarakat tersebut. Objektfikasi merupakan konsekuensi logis dari tahap eksternalisasi. Jika dalam tahap eksternalisasi manusia sibuk melakukan kegiatan fisik dan nonfisik, maka tahap objektifikasi, kegiatan manusia sudah menghasilkan produk-produk budaya. Sedangkan internalisasi ialah tahap di mana realitas objektif hasil masyarakat tersebut kembali dicerap oleh masyarakat itu sendiri, yang merupakan realitas eksternal kembali menjadi realitas internal dan juga memungkinkan untuk diserap oleh masyarakat berbudaya lain dalam bentuk akulturasi budaya. Ibid., 16.

'Idi Subandy Ibrahim dan Dedy Djamaluddin Malik, "Pornografi dan Rekayasa Kenikmatan Massa," dalam Hegemoni Budaya, ed. Idi Subandy Ibrahim (Yogyakarta: Bentang, 1997), 170. 
membedakan manusia dengan makhluk lainnya. ${ }^{7}$ Simbol kebebasan seksual dalam bentuk gambar dan tingkah laku bukan hanya rangkaian simbol atau dunia semu, tapi hal tersebut merupakan upaya praktis dan rasional masyarakat Barat saat berhadapan dengan pengalaman hidup. Budaya liberalisme yang ada pada simbol seksual, mengakibatkan gangguan pada budaya Indonesia. Tataperilaku dan budaya Indonesia menjadi goyah. Ketika ketidakmampuan budaya di Indonesia dalam mempertahankan eksistensinya, mengakibatkan terjadinya distabilitas pada tatanan masyarakat Indonesia. Ketidakstabilan tersebut menjadikan tatanan masyarakat Indonesia pun berubah dan meleburkan diri dengan nilai baru tersebut.

\section{Kebebasan Berekspresi dan Tanggungjawab Etis}

Kata 'bebas' dan 'tanggungjawab etis' menjadi dua kata yang bertautan dalam implementasi sehingga bukan merupakan eufimisisme untuk situasi yang tidak bebas dan tidak bertanggungjawab. ${ }^{8}$ Thomas Szasza mengomentari kaitan antara kebebasan dan tanggungjawab etis ini:

"The crucial moral characteristic of the human condition is the dual experience of freedom of the will and personal responbility. Since freedom and responsibility are two aspects of the same phenomenon, they invite comparison with the proverbial knife that cuts both ways. One of its edges implies option: we call it freedom, the other implies obligations: we call it responbility."

Sebagai makhluk yang beretika, manusia tidak bisa tidak terlibat dalam masalah-masalah etis (ethical issues). Ketika perilaku

${ }^{7}$ Theodore Peterson, Media Massa dan Masyarakat Modern, ter. Haris Munandar dan Dudy Priatna (Jakarta: Kencana, 2003), 28.

8Jalaludin Rakhmat, "Kebebasan Ekspresi dan Tanggungjawab Etis", dalam "Hegemoni Budaya," Idi Subandy Ibrahim dan Dedy Djamaluddin Malik (Yogyakarta: Bentang, 1997), 297.

${ }^{9}$ Thomas Szasz, The Theology Of Medicine (Baton Rouge: Lousiana State University Press, 1977), xiii. 
seseorang mempunyai akibat yang penting bagi orang lain, ketika perilakunya dapat dinilai dengan standar benar dan salah, pada saat itulah masalah etika timbul. Bila perilaku seseorang-fisikal atau simbolis-tidak berpengaruh pada orang lain, bila tidak bebas memilih perilaku, bila dipaksa melakukan suatu, maka saat itu pertimbangan etis sangat minimal (bahkan hampir tidak ada).

Dalam kasus kebebasan yang permisif, yang dapat dilihat dari maraknya kebebasan dalam seksualitas dengan menampakkan diri sebagai orang yang memiliki kebebasan. Namun, mereka itu sebenarnya tidak lagi memiliki kebebasan karena tindakan semau gue yang mereka lakukan menunjukkan bahwa mereka tidak tahu lagi mana yang baik dan mana yang buruk bagi manusia. Perlu diperhatikan bahwa pilihan bebas dalam berekspresi adalah pilihan yang dibuat berdasarkan akal budi. Jika seseorang sudah sampai pada taraf bisa bertindak semaunya sendiri, itu menandakan bahwa akal budinya tidak lagi berfungsi secara normal. Tindakan semau-maunya justru dikendalikan oleh naluri dan perasaan yang tidak dikendalikan secara rasional. Kebebasan tidak berarti kebebasan dari semua prinsip pedoman, bebas disini berarti kebebasan untuk berkembang sesuai dengan struktur eksistensi manusia (pembatasan secara otonom). Ini berarti taat pada hukum-hukum yang mengatur perkembangan manusia yang optimal. Meskipun kodrat bebas, kebebasan manusia selalu bersifat terbatas, tidak ada kebebasan bersifat mutlak. Dengan demikian, bebas berekspresi tetap memiliki hubungan erat dengan harus mempertanggungjawabkan ekspresi tersebut. ${ }^{10}$

\section{Relativitas Pornografi Dan Pornoaksi}

Secara umum relativisme dapat didefinisikan sebagai penolakan terhadap bentuk kebenaran universal tertentu. Sedangkan relatif merupakan yang sesuatu tidak memihak, dan

${ }^{10}$ Rakhmat, Kebebasan..., 260. 
itu tergantung pada sudut pandang yang menilai. Kesamaan yang dimiliki oleh semua bentuk atau subbentuk relatif adalah keyakinan bahwa sesuatu (misalnya, pengetahuan atau moralitas) bersifat relatif terhadap prinsip tertentu dan penolakan bahwa sesuatu itu benar. Saat ini etika menjadi sebuah nilai budaya yang bersifat relatif, ketika etika tersebut dipandang dengan sudut pandang yang berbeda. Relativitas etika adalah pandangan bahwa tidak ada prinsip moral yang benar secara universal; kebenaran semua prinsip moral bersifat relatif terhadap budaya atau pilihan individu. ${ }^{11}$

Mengadili pornografi dan pornoaksi menggunakan tatanan budaya adalah tidak tepat, ini disebabkan karena ketidakmampuan budaya dalam menganalisa dan menghukumi sebuah tatanan baru dari budaya kebebasan. Karena pornografi dan pornoaksi mampu menyembunyikan diri dalam diskursus kebebasan berekspresi dan konteks budaya merupakan suatu masalah tersendiri. Kebebasan berekspresi dengan memperlihatkan bagian tubuh dalam bentuk pornografi dan pornoaksi merupakan dampak budaya impor (baca: Barat), tekanan terhadap dampak ini tidak jauh dari seputar respons masyarakat terhadap aspek sosio-budaya yang menyertainya. ${ }^{12}$

Dalam kaitan ini bisa dipahami bahwa persoalan pornografi dan pornoaksi akhir-akhir ini justru lahir sebagai sebuah bagian (genre) tersendiri dari teks dan budaya mengenai seksualitas, suatu sistem tanda atau simbol yang mengandung makna-makna di sekitar hasrat dan kenikmatan erotisme. Pornografi dan

${ }^{11}$ M.A. Shomali, Relativisme Etika, ter. Zaimul Am (Jakarta: Serambi, 2005), 31. Relativitas etika tersebut dapat dibagi menjadi relativitas individual dan relativitas sosial. Relativitas individual adalah teori bahwa setiap individu berhak menentukan kaidah moralnya sendiri, sedangkan relativitas sosial adalah bahwa setiap masyarakat berhak menentukan norma-normanya sendiri. Kebenaran moral hanyalah kesepakatan kultural di dalam masyarakat. Ibid., 32.

${ }^{12} \mathrm{Ibrahim}$, Pornografi..., 167. 
pornoaksi pada dasarnya sesuatu yang bersifat tekstual, yang sangat tergantung pada kapan, di mana, dengan cara apa dan oleh kepentingan siapa ia dinilai. ${ }^{13}$ Relativitas pornografi dan pornoaksi dapat merugikan dan sekaligus menguntungkan bagi siapa yang berkepentingan dengannya. Sebagai sebuah teks, pornografi dan pornoaksi biasanya memanfaatkan dan mereduksi tubuh perempuan sebagai tanda atau simbol. ${ }^{14}$ Perempuan dimanipulasi ke arah posisinya sebagai "vehicle of meaning," bukan sebagai subjek yang berbicara. Sifat politis yang terkandung di dalamnya merupakan hubungan di antara dua jenis kelamin, laki-laki dan perempuan.

Dengan memahami persoalan pornografi sebagai jalinan simbol atau tanda yang mempresentasikan praktik-praktik, pada satu sisi dilepaskan dari makna prokreatifnya, dan pada sisi lain dari makna sentimental dan kesakralannya. Maka pada titik ini teks pornografi dan pornoaksi justru mendefinisikan hasrathasrat erotik dengan cara mengasingkannya dari konteks kesehatan dan rasionalitas ilmiah, selain itu juga terluput dari analisis estetika. Implikasinya, pelanggaran atas kaidah-kaidah sosial di dalam pornografi dan pornoaksi ditampilkan seolaholah ia merupakan bagian alamiah dari kehidupan sehari-hari, atau seakan-akan ia memang diperbolehkan dan dipraktikkan secara luas oleh masyarakat. Padahal ini dapat menimbulkan shock effect, rasa malu tetapi sekaligus juga menikmatinya.

${ }^{13}$ Lihat Yasraf Amir Piliang, Posrealitas (Jogjakarta: Jalasutra, 2004), 380.

${ }^{14}$ Ada beberapa ciri pada simbol pornografi dan pornoaksi seperti: melakukan pelanggaran atas kaidah-kaidah sosial baku karena ia menampilkan bentuk-bentuk perilaku seksual yang tidak bisa diterima oleh masyarakat dan budayanya (unacceptable) atau ia menampilkan kepada publik tindakan-tindakan seksual yang hanya bisa diterima (acceptable) apabila terdapat di wilayah yang sangat pribadi saja. Menampilkan bentuk-bentuk perilaku seksual yang tidak bisa di terima oleh masyarakat Indonesia saat ini dapat berupa tontonan di media elektroik dan cetak kini tk ubahnya seperti produk, yang dapat dipamerkan, dipromosikan, dan dijual. Lihat, Piliang, Posrealitas.., 353. Lihat juga Ibrahim, Pornografi..., 169. 
Diskursus mengenai seksualitas dan pelanggaran atas kaidah sosial selalu merembes pada persoalan negatif dan relativitas atas nilai yang terkandung, seperti promiskuitas (kebebasan seks), pelacuran, dan pemerkosaan. Terdapat empat kecenderungan akibat dari pornografi dan pornoaksi, di mana pemikiranpemikiran itu sebenarnya terbelenggu pada esensi bagaimana masyarakat melihat perilaku seks itu sendiri sebagai gejala yang secara kontemporer muncul saat ini dalam konstruksi sosial gender. Empat kandungan pemikiran tersebut adalah: pertama, seksualitas selalu dilihat dari sisi esensi dan kebutuhan biologis. Dari sisi esensi, seks selalu diterjemahkan ke dalam pengertian hakekat seks itu sendiri. Sedangkan dari sisi kebutuhan biologis, seks selalu dipandang sebagai kebutuhan manusia secara alamiah. Dengan demikian, maka promiskuitas, pelacuran dan pemerkosaan adalah produk biologis, bukan produk sejarah. Dipihak lain, pandangan sosiokultural melihat dorongan seksual sebagai pengaruh dari sistem sosiokultural yang spesifik. ${ }^{15}$

Kedua, mendefinisikan seksualitas sebagai sebuah ekspresi dari makna dan simbol budaya yang mengelilingi seks biologis dan praktik-praktik seksual, yang secara umum mengacu pada pemikiran konstruksi sosial gender. Pendekatan kontruksi sosial gender megindentifikasi tiga wilayah ekspresi seksual, yaitu abstrak, relatif, dan empirik. Dalam bentuk abstrak, makna seksualitas ditentukan dalam simbol dan bahasa verbal dan kadang-kadang didefinisikan secara longgar sebagai ideologi. Dalam bentuk relatif, makna seksualitas didefinisikan sesuai sosiokultural yang berbeda, sesuai dengan tempat, waktu, dan siapa yang menilai. Sedangkan praktik-praktik seksual dan pranata yang mengancam identitas wanita seperti pelacuran, pornografi, pornoaksi, dan pemerkosaan dianalisis sebagai ekspresi empirik dari gejala-gejala yang lebih mendasar yaitu kontrol pria terhadap seksualitas wanita serta kekerasan pria

${ }^{15}$ Burhan Bungin, Pornomedia (Jakarta: Kencana, 2005), 71. 
terhadap wanita. $^{16}$ Pendekatan ini lebih memusatkan perhatiannya pada wanita (female centered) dan sangat jelas mendefinisikan seksualitas sebagai ungkapan kekuasaan dan kekuatan sosial pria (secara ideologis, institusional maupun tingkah laku) serta menganggap bahwa promiskuitas dan kekerasan sebagai ciptaan pria. ${ }^{17}$

Ketiga, penganut pendekatan historis terhadap hubungan seksual menegaskan peran hubungan ekonomi dalam bentuk norma-norma dan hubungan seksual. Kelompok ini mencoba melihat penekanan kontrol terhadap seksualitas dan kerja wanita dalam pengorganisasian sosial pelahiran dan pemeliharaan anak serta pelayanan rumah tangga. Kemudian kecenderungan ini mencoba melihat seksualitas sebagai suatu konstruksi dari simbol-simbol kebudayaan dan asumsi-asumsi ideologis. Pemikiran ini mendekatkan kita pada konsensus pembagian kerja secara seksual antara wanita dan laki-laki, dan efeknya terhadap konsekuensi sosial ekonomi dalam rumah tangga. Dengan demikian, pada kehidupan gender, laki-laki berfungsi sebagai pencari nafkah, sedangkan wanita berfungsi melahirkan keturunan, memelihara anak, dan mengurus rumah tangga. Penyimpangan seks seperti pelacuran dilihat sebagai sumber pendapatan atau lapangan kerja bagi wanita itu sendiri. ${ }^{18}$

Keempat, persoalan seks bukan sekedar persoalan laki-laki dan perempuan. Tekanan diberikan pada diskursus seks (wilayah

${ }^{16}$ Wanita dipandang sebagai manusia lemah, karena pada dirinya terdapat kekuatan yang mendominasinya. Lihat Ibid. Lihat juga Bambang Sugiharto,"Penjara Jiwa, Mesin Hasrat Tubuh Sepanjang Budaya", Kalam (2000), 34.

${ }^{17}$ Bungin, Pornomedia..., 73.

${ }^{18} \mathrm{Ibid}$. Tubuh juga mampu menjadi sentral dalam ekonomi politik, disebabkan perempuan (estetika, gairah, seksualitas, erotisme) merupakan raison d'etre dalam setiap produksi komoditi. Lihat Piliang, Posrealitas..., 364. Dalam jagad komoditi kapitalisme, terjadi objektifikasi tubuh. Artinya, eksistensinya disamakan dengan objek menjadi bagian dari budaya materi (material culture). Lihat juga ibid., 326. 
pengetahuan), yang diikuti dengan sumber-sumber sosial dan historis serta metode-metode pengaturan dan pengontrolan yang beragam. Persoalan seks dilihat tidak sekedar masalah fertilitas dan erotisme yang berbeda sepanjang garis sejarah dan kelas. Akan tetapi, merambah masuk dalam diskursus yang dominan ditentukan oleh rezim yang berkuasa. Sehingga, akhirnya praktik seks diatur oleh rezim tersebut dan kemudian pribadi-pribadi mengenali dirinya sebagai objek-objek seksual. ${ }^{19}$

Sebagai tatanan yang berada di wilayah relatif, seksualitas dalam pornografi dan erotisme pornoaksi terdapat beberapa perspektif utama dalam masalah ini. ${ }^{20}$ Pertama, perspektif kaum feminis, perspektif ini memandang penyimpangan seksual berupa pelacuran dalam bentuk pornografi dan pornoaksi sebagai hasil dari tekanan masyarakat patriarki dan kapitalis (baca: pebisnis seks). Pandangan ini menitikberatkan pada ketidakseimbangan dan perbedaan seks (lebih dari sekedar persetubuhan liar atau libido yang tinggi). Dalam masyarakat seperti ini, pelacur kerapkali menghadapi berbagai konsekuensi, seperti dicap sebagai pelaku tindakan kriminal yang merendahkan harga dirinya. Sementara para penikmat (baca: pelanggan) pelacur tidak mengalami hal yang demikian. Standar ganda dalam hubungan seks bebas inilah yang menjadi sasaran utama kritik kaum feminis terhadap lembaga-lembaga sosial.

Kedua, perspektif ini menggolongkan seksualitas manusia menjadi enam pandangan, yaitu: (1) Asketisme tradisional, pandangan ini melihat hubungan seksual dari sisi segi gunanya sebagai kegiatan prokreasi dan hanya diizinkan untuk dilakukan di dalam lembaga pernikahan. Posisi seperti ini mengakibatkan generasi muda untuk melakukannya di dalam lembaga pernikahan. Posisi seperti ini mengakibatkan generasi muda yang telah terinternalisasi dengan tradisi ini menghadapi kesulitan

${ }^{19}$ Bungin, Pornomedia..., 74.

${ }^{20}$ Koentjoro, Tutur Dari Sarang Pelacur (Jogjakarta: Tinta, 2004), 42. 
dalam mengekspresikan kebutuhan seksualitas alamiah mereka; (2) Asketisme yang tercerabkan (enlightened ascetism). Mereka memandang hubungan seksual perlu dikontrol dan dimonitor secara hati-hati dan akan terus mendorong orang untuk mengekspresikan kebutuhan dan perasaan seksual selama pemenuhan kebutuhannya sesuai dengan kondisi tertentu dan penuh dengan kehati-hatian; (3) Liberalisme humanistik atau posisi relativistik. Posisi ini memandang aktivitas seksual dapat dilakukan selama itu didasari oleh kesepakatan di antara dua orang yang terlibat didalamnya, semua aktivitas seksual tersebut dibenarkan; (4) Humanistik radikal. Posisi ini dipertimbangkan semua tipe aktivitas seksual sebagai hal yang dapat diterima. Tidak terdapat penolakan terhadap semua tipe perilaku seksual sepanjang tidak melukai secara fisik maupun emosional kedua belah pihak, (5) Fun morality. Menurut konsep ini, seks dipandang sebagai jalan untuk bersenang-senang. Hubungan ini tidak dibatasi secara intensitas, frekuensi atau tipenya sepanjang tidak terjadi kekerasan fisik; (6) Anarki seksual atau seks bebas. Posisi ekstrem yang tidak membatasi tipe seksual. Bebas sebebasnya dalam hal di mana, kapan, dengan siapa atau dengan apa saja. ${ }^{21}$

Ketiga, terdapat empat pendekatan pemikiran dalam perspektif ini sebagai relativitas sebuah tatanan seksualitas. (1) Pemikiran yang dibentuk oleh tradisi empiris. Definisi seksualitas dirumuskan dari anggapan bahwa seks merupakan kebutuhan atau dorongan biologis. Dalam tradisi ini terdapat dua posisi yang berbeda, yaitu pandangan biososial dan sosiokultural.22 Dalam konteks biososial, pola prilaku seksual merupakan sesuatu yang alamiah, muncul dari dorongan seksual yang pada pria lebih kuat dan lebih ekspresif dibandingkan perempuan. Pemikiran yang menganggap seks bebas, pelacuran

${ }^{21}$ Wrightsman L.S, Personality Development In Adulthood (New Bury: Sage Publication, 1988), 213.

22Truong, Sex, Money, And Morality: Prostitution And Tourism In South East Asia (London: Zad Books LTD, 1990), 113. 
dalam bentuk pornografi dan pornoaksi, dan pemerkosaan adalah produk dari interaksi antara dorongan seks dengan sistem sosiokultural yang spesifik, sementara seks bebas dan pemerkosaan adalah pilihan perilaku sosial. Pandangan ini dipengaruhi pemikiran Freud $^{23}$ yang melihat seksualitas dari sudut pandang kebutuhan seksual laki-laki; (2) Pendekatan konstruksi sosial gender yang memandang seksualitas sebagai ekspresi makna kultural dan simbol dalam lingkup seks biologis dan praktik seksual. Pendekatan ini berpihak pada perempuan, di mana seksualitas dipandang sebagai ekspresi dari kekuatan sosial laki-laki; (3) Pendekatan historis-ideologis yang dibangun dari teori Engels yang mengadopsi pendekatan historis dalam hubungan seksual. Seksualitas didefinisikan sebagai sesuatu yang konstan, baik dalam pengertian biologis maupun ideologis. Definisi ini menekankan eksistensi mayoritas dalam diskursus tentang seks (dalam bidang pengetahuan), keanekaragaman sosial, asal usul historis, serta kesetaraan dalam keanekaragaman regulasi dan kontrol yang diperlukan. Seksualitas dipahami sebagai segresi hubungan sosial yang secara historis ruang lingkupnya spesifik. Diskursus dominan ini dihubungkan dengan rezim kuasa yang mengatur bentuk praktik dan bentuk perilaku yang dikenali individu sebagai objek seksual. ${ }^{24}$

\footnotetext{
23Sigmud Freud dilahirkan pada tanggal 6 Mei 1856 di kota Freiberg, Moravia, wilayah Czechoslavakia (dahulu) dari ayah dan ibu Yahudi. Pada tahun 1886, Freud melakukan studi tentang masalah-masalah syaraf secara umum, dan histeria secara khusus dengan menggunakan obat bius magnetis, yang antar lain di tulis dalam karyanya Interpretation Of Dream. Di Wina, Freud mendirikan sebuah "Pusat Pengkajian Ilmiah." Masyarakat di Swiss dan Eropa pada umumnya banyak berhubungan dengannya. Hal itu telah mengantarkan pada terselenggarakannya sebuah konferensi pertama bagi penganut psikoanalisis pada tahun 1908. Lihat WAMY, Gerakan Keagamaan Dan Pemikiran (Akar Ideologis Dan Penyebarannya), ter. A. Najiyullah (Jakarta Timur: al I'tishom, 2006), 287.

${ }^{24}$ Koentjoro, Tutur..., 48. Lihat juga Yasraf Amir Piliang, Dunia Yang Berlari (Jakarta: Gramedia, 2004), 212.
} 
Dengan perbedaan pandangan dan pendapat sebagai bentuk relatifitas pornografi dan pornoaksi tersebut, maka sulit untuk menyimpulkan benar salah atau normatifnya perilaku penyimpangan seksual dari segi historis-kultural. Nilai-nilai yang terkandung dalam tatanan budaya juga dipengaruhi oleh tempat (geografi), waktu, dan oleh siapa yang menilai.

\section{Telaah Islam terhadap Manusia dan Budaya Kebebasan}

Manusia sebagai subyek kebudayaan memiliki kaitan yang erat dengan hasil kebudayaan itu sendiri. Dengan akal budi manusia mampu memikirkan konsep-konsep dan menyusun prinsip-prinsip umum yang diikhtiarkan sebagai pengamatan dan percobaan. $^{25}$ Dengan akal budinya pula manusia mampu menjadikan keindahan dan Allah telah memberikan dorongan kepada manusia untuk memikirkan alam semesta, mengadakan pengamatan terhadap berbagai gejala alam. Seruan untuk mengadakan tinjauan, pemikiran, penelitian dan pembahasan ilmiah dapat ditemukan dalam berbagai ayat dalam Qs. AlAnkabut (29): $20^{26}$ dan Qs. Yunus (10): 101.27

Dengan seruan Allah itu manusia dengan akal budi dan ilmu pengetahuannya dituntut untuk mampu menciptakan piranti kehidupannya, yaitu kebutuhan rohani, fisik, dan kebutuhan sosialnya. Budaya sebagai piranti kebutuhan sosial manusia, dalam islam wujud budaya harus selalu berada dalam kerangka tauhid dan takwa. ${ }^{28}$ Setelah manusia mampu menciptakan budaya, sekaligus sebagai tatanan hidupnya maka manusia tersebut terikat aktif pula olehnya. Dengan akal budi tersebut

${ }^{25}$ Rohiman Notowidagdo, Ilmu Budaya Dasar Berdasarkan Al Quran Dan Hadist (Jakarta: Rajawali, 2002), 22.

26Artinya: "Katakanlab: Berjalanlah di (muka) bumi, maka perhatikanlah bagaimana Allab menciptakan (dunia) dari permulaannya".

${ }^{27}$ Artinya: "Katakanlah: Perhatikanlah apa yang ada di langit dan di bumi".

${ }^{28}$ Nourouzzaman Shiddiqi, Jeram-Jeram Peradaban Muslim (Yogyakarta: Pustaka Pelajar, 1996), 275. 
menunjukkan secara jelas bahwasanya islam menganggap manusia memiliki kebebasan. ${ }^{29}$ Dengan implikasi ganjaran pahala dari Allah bila berbuat kebaikan dan siksa di akherat bila melakukan tindakan kejahatan Dengan balasan yang jelas maka manusia mampu membimbing diri dengan akal budinya.

Adapun faktor yang mendorong kebudayaan Islam berkembang, sekaligus merupakan limit kebudayaan dalam masyarakat Islam adalah: ${ }^{30}$

1) Agama Islam menghormati akal manusia dan meletakkannya ditempat terhormat, menyuruh manusia untk mempergunakan akal untuk memeriksa dan memikirkan keadaan alam. ${ }^{31}$

2) Agama Islam mewajibkan tiap-tiap pemeluknya, laki-laki dan perempuan untuk menuntut ilmu. ${ }^{32}$

3) Agama Islam melarang bertaklid buta, menerima sesuatu sebelum diperiksa. ${ }^{33}$

4) Agama Islam mengarahkan agar umat Islam selalu mengadakan barang yang belum ada, merintis jalan yang belum ditempuh, dan membuat inisiatif dalam hal keduniaan yang memberi manfaat untuk masyarakat.

5) Agama Islam menyuruh pemeluknya untuk mencari kerelaan Tuhan dengan semua nikmat yang telah diterimanya dan menyuruh mempergunakan hak-hak atas dunia dalam pemimpin dan peraturan agama. ${ }^{34}$

6) Agama Islam menganjurkan pemeluknya agar meninggalkan kampungnya, berjalan ke negeri lain, menyambung

${ }^{29}$ M. Syaltout, Islam Sebagai Aqidah Dan Syariah, ter. Bustani A. Gani dan B. Hamdany Ali (Jakarta: Bulan Bintang, 1985), 95.

${ }^{30}$ Endang Saifuddin Anshori, W awasan Islam Pokok-Pokok Pikiran Tentang Paradigma Dan Sistem (Jakarta: Gema Insani, 2004), 120.

${ }^{31}$ Qs. al-Imron (3): 189-190.

${ }^{32}$ Qs. al-Mujâdalah (58): 11.

${ }^{33}$ Qs. al-Isro' (17): 36.

${ }^{34}$ Qs. al-Qoshâsh (28): 77. 
silaturrahim dengan bangsa dan golongan lain, saling bertukar pengetahuan. ${ }^{35}$

7) Agama Islam memerintahkan untuk memeriksa kebenaran walaupun datangnya dari kaum yang berlainan bangsa dan kepercayaan. ${ }^{36}$

Dengan faktor kebudayaan Islam dan perintah yang jelas tersebut, maka manusia khususnya umat Islam sebagai subyek kebudayaan Islam memiliki kebebasan yang tetap menggunakan al-Quran dan hadis sebagai pijakan dasar dalam berbudaya dan memiliki tanggungjawab atasnya. Masih berbaurnya makna kebebasan berekspresi dengan mengumbar nilai-nilai seksualitas dengan pornografi dan pornoaksi ala Barat dan kebebasan dalam ranah agama (baca: Islam) dan ketidakmampuan memilahnya, mengkibatkan pemeluk agama tersebut terseret dalam kebebasan yang jauh dari dalîl syari' dan hanya berpegang pada dalîl naqlî yang mereka jadikan justifikasi atas kebebasan berekspresi tersebut. Adapun pandangan Islam mengenai kebebasan berekspresi dalam bentuk pornografi dan pornoaksi adalah tidak dibenarkan, dengan adanya beberapa teks al-Quran sebagai penegasnya. Surat al-Isrâ (17): 32, melarang setiap orang mendekati zina, surat al-Nûr (35): 30, mengatur tentang tata pergaulan dan berbusana bagi kaum laki-laki dan ayat 31 mengatur tentang tata pergaulan dan berbusana bagi kaum perempuan. Surat al-Ahzâb (33): 59, memerintahkan kepada Nabi Muhammad saw. agar kaum perempuan mengulurkan jilbabnya ke seluruh tubuhnya (tata busana). ${ }^{37}$

Sebagai pembelajaran mengenai kebebasan sesuai syari'at atau sikap yang islami dan usaha untuk membentengi diri dari kebebasan yang tidak berpijak pada al-Quran sejak kecil ialah dapat dilakukan dengan:

${ }^{35}$ Qs. al-Hâjj (22): 46.

${ }^{36}$ Qs. Thâha (20): 17-18.

${ }^{37}$ Djubaedah, Pornografi ..., 12. 
1. Menanamkan rasa malu pada anak. Rasa malu harus ditanamkan kepada anak sejak dini. Jangan biasakan anakanak, walau masih kecil, bertelanjang di depan orang lain; misalnya ketika keluar kamar mandi, berganti pakaian dan sebagainya. Membiasakan anak perempuan sejak kecil berbusana muslimah menutup aurat juga penting untuk menanamkan rasa malu.

2. Menanamkan jiwa maskulinitas pada anak laki-laki dan jiwa feminitas pada anak perempuan. Laki-laki dan perempuan mempunyai perbedaan mendasar. Perbedaan tersebut telah diciptakan sedemikian rupa oleh Allah. Mengingat perbedaan tersebut, islam telah memberikan tuntutan agar masingmasing fitrah yang telah ada tetap terjaga. Islam menghendaki agar laki-laki memiliki kepribadian maskulin dan perempuan memiliki kepribadian feminin. Islam tidak menghendaki wanita menyerupai laki-laki, begitu juga sebaliknya.

3. Memisahkan tempat tidur mereka. Usia antara 7-10 tahun merupakan usia saat anak mengalami perkembangan yang pesat. Anak mulai melakukan eksplorasi ke dunia luar. Anak tidak hanya berpikir sesuatu yang ada di luar dirinya. Pemisahan tempat tidur merupakan upaya untuk menanamkan tentang eksistensi dirinya. Jika pemisahan tempat tidur terjadi antara anak telah dilatih untuk berani mandiri. Anak juga dicoba untuk belajar melepaskan perilaku lekatnya (attachment behavior) dengan orang tuanya. Jika pemisahan tempat tidur dilakukan terhadap anak dengan saudaranya yang berbeda jenis kelamin, secara langsung ia telah ditumbuhkan kesadarannya tentang eksistensi perbedaan jenis kelamin.

4. Mendidik anak agar selalu menjaga pandangan mata. Telah menjadi fitrah bagi setiap manusia untuk tertarik dengan lawan jenisnya. Namun, jika fitrah tersebut dibiarkan bebas lepas tanpa kendali, justru hanya akan merusak kehidupan 
manusia itu sendiri. Begitu pula dengan mata yang dibiarkan melihat gambar-gambar atau film yang mengandung unsur pornografi.

5. Mendidik anak agar tidak melakukan ikhtilât. Ikhtilât adalah bercampur baurnya laki-laki dan perempuan bukan mahram tanpa adanya keperluan yang dibolehkan oleh syariat Islam. Ikbtilât dilarang karena interaksi semacam ini bisa menjadi mengantarkan pada perbuatan zina yang diharamkan Islam. Karena itu, jangan biasakan anak diajak ke tempat-tempat yang di dalamnya terjadi percampuran laki-laki dan perempuan secara bebas.

7. Mendidik anak agar tidak melakukan khalwat. Dinamakan khalwat jika seorang laki-laki dan wanita bukan mahram-nya berada di suatu tempat, hanya berdua saja. Biasanya mereka memilih tempat yang tersembunyi, yang tidak bisa dilihat oleh orang lain. ${ }^{38}$

Itulah beberapa hal yang harus diterapkan dan untuk membentengi diri sesuai aturan-aturan Islam dari pengaruh buruk kebebasan berekspresi ala Barat yang tidak bertanggungjawab.

\section{Catatan Akhir}

Melalui tulisan di atas, dapat ditegaskan perwujudan penyimpangan seksual yang terjadi selama ini, tidak jauh dari pengaruh budaya Barat berupa kebebasan mengekspresikan simbol seksualitas diri di mana masyarakat Indonesia tidak mampu membendungnya melalui tatanan adat istiadat. Ini juga dapat dilihat dari pengaruh pemikiran Freud yang mengganggap penyimpangan seksual bukan hal yang negatif, tetapi perilaku tersebut merupakan kinerja hormonal yang lumrah dan tidak bisa dicegah.

38Zulia Ilmawati,'Pendidikan Seks Untuk Anak", Al Wa'ie, 30 April 2006, 25. 
Budaya kebebasan berekspresi dalam bentuk pornografi dan pornoaksi sebagaian masyarakat Indonesia dijadikan sebagai aktivitas tertutup dan terbatas. Pornografi dan pornoaksi tersebut kemudian dijadikan realitas objektif yang pengejawantahannya dapat berupa teknologi, gambar, patung, lukisan, dan lain-lain.

Perwujudan perilaku penyimpangan seksual di dalam masyarakat Indonesia bermula dari nilai-nilai budaya yang sangat relatif terhadap masalah-masalah kontemporer, yaitu perilaku budaya seks bebas dalam bentuk gambar (pornografi) dan gerakan erotis (pornoaksi). Dalam tatanan budaya dan adat istiadat di Indonesia, budaya seks bebas masih tetap sulit diterima secara umum, selain masih terdapatnya budaya yang sangat mengikat secara pribadi, terdapat pula nilai-nilai religiusitas yang ada dan masih kuat di masyarakat Indonesia. Terhadap pelbagai bentuk ekspresi kebebasan yang terdapat dalam budaya Barat dan sekarang melebur dalam masyarakat Indonesia, Islam melihat bahwa tradisi kebebasan tersebut bertentangan dengan argumen-argumen normatif dalam alQur'an agar manusia tidak menjadikan hawa nafsunya sebagai berhala. Wa al-Lâh a lam.

\section{Daftar Pustaka}

Bambang Sugiharto, "Penjara Jiwa, Mesin Hasrat Tubuh Sepanjang Budaya", Kalam (2000).

Burhan Bungin, Pornomedia (Jakarta: Kencana, 2005).

Chris Barker, Cultural Studies: Teori dan Praktik, ter. Nurhadi (Jogjakarta: Kreasi Wacana, 2004).

Djoko Widhagdo, Ilmu Budya Dasar (Jakarta: Bumi Aksara, 2004).

Endang Saifuddin Anshori, Wawasan Islam Pokok-Pokok Pikiran Tentang Paradigma Dan Sistem (Jakarta: Gema Insani, 2004).

Hery Sidgwick, Outlines Of The History Of Ethics (London: Macmilan, 1967). 
Idi Subandy Ibrahimdan Dedy Djamaluddin Malik (ed.), Hegemoni Budaya (Yogyakarta: Bentang, 1997).

K. Bertans, Etike (Jakarta: Gramedia, 1993).

Koentjoro, Tutur Dari Sarang Pelacur (Jogjakarta: Tinta, 2004).

M. Syaltout, Islam Sebagai Aqidah Dan Syariah, ter. Bustani A. Gani dan B. Hamdany Ali (Jakarta: Bulan Bintang, 1985).

M.A. Shomali, Relativisme Etika, ter. Zaimul Am Jakarta: Serambi, 2005).

Nourouzzaman Shiddiqi, Jeram-Jeram Peradaban Muslim (Yogyakarta: Pustaka Pelajar, 1996).

Rafael Raga Maran, Manusia dan Kebudayaan: Dalam Perspektif Ilmu Budaya Dasar (Jakarta: Rineka Cipta, 2000).

Rohiman Notowidagdo, Ilmu Budaya Dasar Berdasarkan Al Quran Dan Hadist (Rajawali: Jakarta, 2002).

Sigmund Freud, Memperkenalkan Psikoanalisa, ter. K. Bertens (Jakarta: Gramedia, 1979). , Sekelumit Sejarah Psikoanalisa, ter. K. Bertens (Jakarta: Gramedia, 1986). 2002).

Theodore Peterson, Media Massa dan Masyarakat Modern, ter. Haris Munandar dan Dudy Priatna Jakarta: Kencana, 2003).

Thomas Szasz, The Theology Of Medicine (Baton Rouge: Lousiana State University Press, 1977).

Truong, Sex, Money, And Morality: Prostitution And Tourism In South East Asia (London: Zad Books LTD, 1990).

WAMY, Gerakan Keagamaan Dan Pemikiran (Akar Ideologis Dan Penyebarannya), ter. A. Najiyullah (Jakarta: al I'tishom, 2006).

Wrightsman L.S, Personality Development In Adulthood (New Bury: Sage Publication, 1988).

Zulia Ilmawati,"Pendidikan Seks Untuk Anak", Al Wa'ie (30 April 2006). 